\title{
Sepsis impairs microvascular autoregulation and delays capillary response within hypoxic capillaries
}

\author{
Ryon M. Bateman ${ }^{1,2,3^{*}}$, Michael D. Sharpe ${ }^{4}$, Justin E. Jagger ${ }^{1}$ and Christopher G. Ellis ${ }^{1}$
}

\begin{abstract}
Introduction: The microcirculation supplies oxygen $\left(\mathrm{O}_{2}\right)$ and nutrients to all cells with the red blood cell (RBC) acting as both a deliverer and sensor of $\mathrm{O}_{2}$. In sepsis, a proinflammatory disease with microvascular complications, small blood vessel alterations are associated with multi-organ dysfunction and poor septic patient outcome. We hypothesized that microvascular autoregulation-existing at three levels: over the entire capillary network, within a capillary and within the erythrocyte — was impaired during onset of sepsis. This study had three objectives: 1) measure capillary response time within hypoxic capillaries, 2) test the null hypothesis that RBC $\mathrm{O}_{2}$-dependent adenosine triphosphate (ATP) efflux was not altered by sepsis and 3) develop a framework of a pathophysiological model.
\end{abstract}

Methods: This was an animal study, comparing sepsis with control, set in a university laboratory. Acute hypotensive sepsis was studied using cecal ligation and perforation (CLP) with a 6-hour end-point. Rat hindlimb skeletal muscle microcirculation was imaged, and capillary $\mathrm{RBC}$ supply rate $(\mathrm{SR}=\mathrm{RBC} / \mathrm{s}), \mathrm{RBC}$ hemoglobin $\mathrm{O}_{2}$ saturation $\left(\mathrm{SO}_{2}\right)$ and $\mathrm{O}_{2}$ supply rate $\left(\mathrm{qO}_{2}=\mathrm{pLO}_{2} / \mathrm{s}\right)$ were quantified. Arterial $\mathrm{NOx}$ (nitrite + nitrate) and $\mathrm{RBC} \mathrm{O}_{2}$-dependent ATP efflux were measured using a nitric oxide (NO) analyzer and gas exchanger, respectively.

Results: Sepsis increased capillary stopped-flow $(p=0.001)$ and increased plasma lactate $(p<0.001)$. Increased plasma $\mathrm{NOx}(p<0.001)$ was related to increased capillary RBC supply rate $(p=0.027)$. Analysis of 30 -second $\mathrm{SR}_{-} \mathrm{SO}_{2}-\mathrm{qO}_{2}$ profiles revealed a shift towards decreased $(p<0.05) \mathrm{O}_{2}$ supply rates in some capillaries. Moreover, we detected a three- to fourfold increase $(p<0.05)$ in capillary response time within hypoxic capillaries (capillary flow states where $\mathrm{RBC} \mathrm{SO} \mathrm{S}_{2}<20 \%$ ). Additionally, sepsis decreased the erythrocyte's ability to respond to hypoxic environments, as normalized RBC $\mathrm{O}_{2}$-dependent ATP efflux decreased by $62.5 \%(p<0.001)$.

Conclusions: Sepsis impaired microvascular autoregulation at both the individual capillary and erythrocyte level, seemingly uncoupling the $\mathrm{RBC}$ acting as an " $\mathrm{O}_{2}$ sensor" from microvascular autoregulation. Impaired microvascular autoregulation was manifested by increased capillary stopped-flow, increased capillary response time within hypoxic capillaries, decreased capillary $\mathrm{O}_{2}$ supply rate and decreased $\mathrm{RBC}_{2}$-dependent ATP efflux. This loss of local microvascular control was partially off-set by increased capillary RBC supply rate, which correlated with increased plasma NOx.

\footnotetext{
* Correspondence: ryon.bateman@gmail.com

'Department of Medical Biophysics, University of Western Ontario, London,

ON, Canada

${ }^{2}$ Department of Biochemistry, Keio University School of Medicine, Tokyo, Japan

Full list of author information is available at the end of the article
} 


\section{Introduction}

The microcirculation is a highly integrated and functional system [1] that delivers oxygen $\left(\mathrm{O}_{2}\right)$ and nutrients and removes waste products and heat from cells, thereby maintaining cell function and making the microcirculation essential for muscle and organ function. The microcirculation has distinctive architecture, with the skeletal muscle microvasculature investigated in this study consisting of feeding arterioles, capillary networks and collecting venules. A hallmark of sepsis is an early onset microvascular dysfunction, within 6-24 hours in animal models, characterized by increased capillary stoppedflow and a maldistribution of microvascular blood flow [2-4]. De Backer et al [5] were the first to report that outcome in septic patients was related to small vessel perfusion density in the sublingual microcirculation and more recent studies have underscored the importance of microvascular dysfunction in multiple organ failure and patient mortality [6-8].

However, while previous experimental studies have implied an impairment of microvascular autoregulation $[2-4,9]$, this is not completely understood. Moreover, the effect of sepsis on the capillary response within hypoxic capillaries (micro-tissue regions with low capillary red blood cell (RBC) hemoglobin $\mathrm{O}_{2}$ saturation $\left(\mathrm{SO}_{2}\right)$ and low tissue oxygenation) is unknown. The significance is that impairment of the microvascular autoregulatory system would uncouple local $\mathrm{O}_{2}$ delivery from local $\mathrm{O}_{2}$ demand leaving some tissue regions vulnerable to hypoxia, and possible dysfunction. Evidence suggests the microcirculation can modulate regional capillary flows via erythrocyte $\mathrm{O}_{2}$-dependent ATP signaling from hypoxic RBCs [10, 11]. Our working hypothesis is that ATP released from hypoxic RBCs [12, 13], via a deoxyhemoglobin/glycolytic enzyme molecular switch at the inner RBC membrane [13-15], can bind to purinergic type 2 (P2Y) receptors on endothelial cells and trigger a conducted vascular response [9] via endothelial cells to upstream resistance vessels, which respond via nitric oxide (NO)-mediated modulation of vascular tone resulting in increased downstream $\mathrm{RBC}$ supply rate $[10,16,17]$. Whether this $\mathrm{RBC}$ function is altered during sepsis is unknown.

Accordingly, in this study of the early onset effects of sepsis on microvascular function, we considered two related but unknown aspects of the microvascular autoregulatory system. First we measured the microvascular in vivo capillary response time within hypoxic capillaries (capillary $\mathrm{RBC} \mathrm{SO}_{2}<20 \%$ ) at the arteriolar and venular end of the skeletal muscle capillary network and second we tested the null hypothesis that sepsis would not alter $\mathrm{RBC} \mathrm{O}_{2}$-dependent ATP efflux. We then incorporated these findings into a multifactorial model of microvascular pathophysiology based on current evidence.

\section{Methods}

\section{Animal model of sepsis}

Experimental protocols were approved by the University of Western Ontario Council on Animal Care. Sepsis was studied using a saline fluid resuscitated, hypotensive animal model as previously described [2]. The study design was a comparison between two groups undertaken in a University setting. In brief, 11 male Sprague-Dawley rats were divided randomly into sham/control and cecal ligation and perforation (CLP) groups. Sepsis was induced in anesthetized animals by perforating the cecum and expressing the fecal contents into the peritoneal cavity. Animals were cannulated for fluid resuscitation (0.9\% saline, 18 mg. $\mathrm{kg}^{-1} \cdot$ hour $\left.^{-1}\right)$, monitoring mean arterial pressure and blood collection. A tracheotomy was performed for mechanical ventilation with fraction of inspired $\mathrm{O}_{2}=0.3$. Core temperature was maintained at $36.5-37.2{ }^{\circ} \mathrm{C}$. The right hind limb extensor digitorum longus skeletal muscle was isolated and repositioned into the optical path. Animals were stabilized and microvascular images acquired from 4-6 hours after the septic injury. See Additional file 1 for data supplement and detailed description.

\section{Blood samples and NOx, lactate and $\mathrm{RBC} \mathrm{O}_{2}$-dependent ATP analysis}

Arterial blood was collected to establish normal blood gases at the outset and again at 6 hours for $\mathrm{NOx}$ $\left(\mathrm{NO}_{2}^{-}+\mathrm{NO}_{3}^{-}\right)$, lactate and ATP efflux analysis. $\mathrm{NOx}$ was measured using a $\mathrm{NO}$ analyzer as previously described [18, 19]. RBC $\mathrm{O}_{2}$-dependent ATP efflux was measured using a custom gas exchanger. In brief, arterial whole blood was equilibrated under normoxic $(\mathrm{N})$ then subjected to hypoxic conditions $(\mathrm{H})$, for 5 minutes respectively, as previously described [13]. ATP efflux was normalized as the $\mathrm{H} / \mathrm{N}$ ratio. See Additional file 1 for data supplement and detailed description.

\section{Functional microvascular imaging}

A dual wavelength imaging system acquired optical density (OD 420, $430 \mathrm{~nm}$ ) information from the skeletal muscle microcirculation, as previously described $[3,20]$. In brief, capillary $\mathrm{RBC}$ supply rate $(\mathrm{SR}=\mathrm{RBC} / \mathrm{s})$ was calculated from $\mathrm{RBC}$ velocity and lineal density measurements [3], and $\mathrm{RBC} \mathrm{SO}_{2}$ was calculated from the OD430/420 ratio [21]. Capillary oxygen supply rate $\left(\mathrm{qO}_{2}\right)$ was then calculated from RBC SR and $\mathrm{SO}_{2}$, where $\mathrm{qO}_{2}\left(\mathrm{pLO}_{2} / \mathrm{s}\right)=$ $\mathrm{SR} \times \mathrm{SO}_{2} \times \mathrm{k}$, where $\mathrm{k}=0.0362 \mathrm{pL} \mathrm{O}_{2} / \mathrm{RBC}$ at $100 \% \mathrm{SO}_{2}$ [3]. Heterogeneity in $\mathrm{RBC}$ SR and $\mathrm{qO}_{2}$ was calculated as the coefficient of variation (SD/mean) from 30-second profiles. Random fields of view were imaged and recorded. During off-line analysis, a three-line reference grid was used to quantify functional capillary density (caps/mm), as either continuous, intermittent (RBC flow came to arrest 
at least once) or stopped-flow (arrested RBC flow) based on 30-second analysis of flow behavior [22]. Capillary response time was assessed as the time required to restore $\mathrm{RBC} \mathrm{SO}_{2}$ to $>20 \%$. See Additional file 1 for data supplement and detailed description of capillary hemodynamics and RBC $\mathrm{SO}_{2}$ measurements, see Additional file 2 for a video clip of capillary RBC hemodynamics and see Additional file 3 for a video clip of capillary $\mathrm{RBC} \mathrm{SO}_{2}$ measurements.

\section{Statistics}

All values are reported as mean $\pm \mathrm{SE}$ unless otherwise stated. $P$ values less than 0.5 were considered statistically significant. Comparisons between CLP and sham group variables were made using the student's $t$-test or MannWhitney Rank Sum test. Linear regression was used to test the relationship between capillary RBC SR and plasma NOx. Chi-squared analysis was used to test the null hypothesis that no difference in capillary $\mathrm{O}_{2}$ supply distribution (low, average, high) existed between sham and CLP. SigmaStat 3.0 software (Point Richmond, CA, USA) was used for statistical analysis.

\section{Results}

Acute physiological responses to septic injury are shown in Table 1. CLP animals had normal respiratory gases, decreased mean arterial pressure and decreased $\mathrm{pH}$ $(p<0.001)$. Though hemoglobin was higher in the CLP group, hemoglobin remained in the normal range $(11.5-16.1 \mathrm{~g} / \mathrm{dL})$ in both groups. Both plasma metabolites, lactate and NOx (oxidized metabolites of nitric oxide, $\mathrm{NO}_{2}^{-}+\mathrm{NO}_{3}^{-}$) increased in CLP animals by the 6-hour end-point $(p<0.001$; Table 1$)$. Regression analysis found increasing arterial plasma NOx levels were related to increasing capillary $\mathrm{RBC}$ SR $(p=$ 0.027; Fig. 1).

Table 1 Physiological parameters at 6-hour end-point

\begin{tabular}{llll}
\hline Variable & Sham $(n=6)$ & $\mathrm{CLP}(\mathrm{n}=5)$ & $\mathrm{p}$ value \\
\hline Weight $(\mathrm{g})$ & $162 \pm 3.3$ & $164.5 \pm 1.5$ & $\mathrm{NS}$ \\
Cardiovascular and blood gases & & & \\
$\quad$ Mean arterial pressure $(\mathrm{mmHg})$ & $103.6 \pm 2.9$ & $68.8 \pm 3.9$ & $<0.001$ \\
Arterial $\mathrm{PO}_{2}(\mathrm{mmHg})$ & $97.6 \pm 5.4$ & $108 \pm 2.2$ & $\mathrm{NS}$ \\
$\quad$ Arterial $\mathrm{SO}_{2}(\%)$ & $94.1 \pm 2.5$ & $92.7 \pm 1.5$ & $\mathrm{NS}$ \\
Arterial $\mathrm{pCO}_{2}(\mathrm{mmHg})$ & $37.5 \pm 2.9$ & $34.9 \pm 2.9$ & $\mathrm{NS}$ \\
$\mathrm{pH}$ & $7.43 \pm 0.01$ & $7.32 \pm 0.03$ & $<0.001$ \\
Hemoglobin $(\mathrm{g} / \mathrm{dL})$ & $11.8 \pm 0.3$ & $14.9 \pm 0.2$ & $<0.001$ \\
Plasma metabolites & & & \\
Lactate $(\mu \mathrm{M})$ & $1.1 \pm 0.1$ & $2.1 \pm 0.1$ & $<0.001$ \\
Arterial NOx $(\mu \mathrm{M})$ & $18.1 \pm 1.5$ & $42.6 \pm 4.1$ & $<0.001$ \\
\hline
\end{tabular}

Values are mean \pm SE. Normal rat hemoglobin (11.5-16.1 g/dL). CLP Cecal ligation and perforation, $\mathrm{NO} \times \mathrm{NO}_{2}^{-}+\mathrm{NO}_{3}^{-}, \mathrm{NS}$ Nonsignificant, $\mathrm{PCO}_{2}$ Partial pressure of carbon dioxide, $\mathrm{PO}_{2}$ Partial pressure of oxygen, $\mathrm{SO}_{2}$ Oxygen saturation

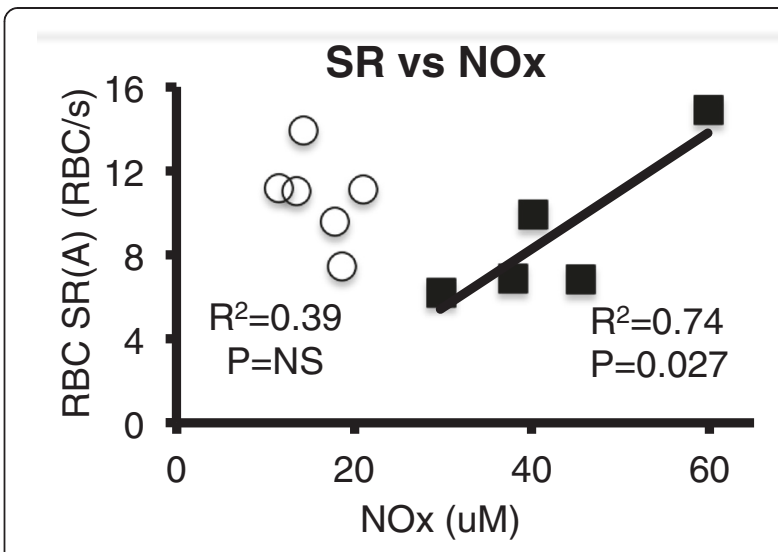

Fig. 1 Relationship between capillary red blood cell (RBC) supply rate (SR) and plasma $\mathrm{NO}_{2}^{-}+\mathrm{NO}_{3}^{-}(\mathrm{NOx})$. $\mathrm{RBC}$ supply rate $(\mathrm{RBC} / \mathrm{s})$ at the arteriolar end of capillaries in hind limb skeletal muscle was measured using a functional microvascular imaging system, as described in the Methods. Plasma NOx was measured in arterial blood samples, as described in the Methods. Linear regression detected a significant relationship between capillary RBC supply rate and plasma NOx level in septic animals (black boxes). White circles = sham

\section{Capillary $\mathrm{RBC}$ SR and $\mathrm{qO}_{2}$}

Variation in capillary $\mathrm{RBC}$ SR $(\mathrm{RBC} / \mathrm{s}), \mathrm{qO}_{2}\left(\mathrm{pLO}_{2} / \mathrm{s}\right)$ and their respective 30-second coefficients of variation, at arteriolar and venular ends of capillary networks, are shown as box plots for each animal in Additional file 4: Figure S3. Confidence intervals (95\%) for control capillary RBC SR and $\mathrm{qO}_{2}$, used to categorize RBC SR (as slow, average, fast) and $\mathrm{qO}_{2}$ (as low, average, high) in all experiments are shown in Additional file 5: Table S1. The relationships between capillary $\mathrm{qO}_{2}$ and $\mathrm{RBC}$ SR in single sham and CLP experiments are shown in Additional file 6: Figure S4. Table 2 summarizes the $\mathrm{RBC}$ SR and $\mathrm{qO}_{2}$ data at the arteriolar and venular ends of capillaries. While no significant differences in mean capillary RBC SR were detected at either the arteriolar or venular ends of capillary networks, there was a trend $(p=0.092)$ towards increased variation in venular end capillary RBC SR in CLP animals. However, capillary oxygen supply rates were found to decrease at both arteriolar and venular ends of capillary networks $(p=0.002)$ and have more variability (measured as the coefficient of variation) in their 30-second signal. Of note is that some extremely fast capillary RBC supply rates and high oxygen supply rates were detected in some animals (Additional file 4: Figure S3).

The significance is that some regions of the CLP skeletal muscle microcirculation had fast RBC supply rates 9-18 times faster with higher oxygen supply rates supplying from 17 to 26 times more $\mathrm{O}_{2}$ than slower capillaries, while other capillaries with stopped-flow were no longer delivering $\mathrm{O}_{2}$ to local tissue. Consistent with an average drop in $\mathrm{qO}_{2}$ across the capillary bed, there was a trend towards a two-fold increase in capillary $\mathrm{O}_{2}$ extraction in CLP 
Table 2 Capillary perfusion, $\mathrm{O}_{2}$ transport, functional capillary density, capillary and RBC function

\begin{tabular}{|c|c|c|c|}
\hline Variable & Sham $(n=6)$ & $\mathrm{CLP}(\mathrm{n}=5)$ & $p$ value \\
\hline \multicolumn{4}{|l|}{ Capillary perfusion $/ \mathrm{O}_{2}$ transport } \\
\hline \multicolumn{4}{|l|}{ RBC SR variation } \\
\hline art SR (RBC/s) & $10.8 \pm 0.9$ & $9.0 \pm 1.6$ & NS \\
\hline art SR (RBC/s) CV (\%) & $43.1 \pm 4.3$ & $48.8 \pm 2.4$ & NS \\
\hline ven SR (RBC/s) & $9.7 \pm 1.5$ & $7.6 \pm 1.1$ & NS \\
\hline ven SR (RBC/s) CV (\%) & $42.8 \pm 5.7$ & $58.6 \pm 7.6$ & $=0.092$ \\
\hline \multicolumn{4}{|l|}{$\mathrm{qO}_{2}$ variation } \\
\hline art $\mathrm{qO}_{2}\left(\mathrm{pLO}_{2} / \mathrm{s}\right)$ & $20.7 \pm 1.2$ & $14.4 \pm 2.1$ & $=0.013$ \\
\hline art $\mathrm{qO}_{2}\left(\mathrm{pLO}_{2} / \mathrm{s}\right) \mathrm{CV}(\%)$ & $55.4 \pm 5.8$ & $76.4 \pm 6.5$ & $=0.024$ \\
\hline ven $\mathrm{qO}_{2}\left(\mathrm{pLO}_{2} / \mathrm{s}\right)$ & $16.9 \pm 1.9$ & $8.3 \pm 1.1$ & $=0.002$ \\
\hline ven $\mathrm{qO}_{2}\left(\mathrm{pLO}_{2} / \mathrm{s}\right) \mathrm{CV}(\%)$ & $59.7 \pm 6.0$ & $79.3 \pm 8.1$ & $=0.054$ \\
\hline Capillary $\mathrm{O}_{2}$ ER (\%) & $19.1 \pm 8.0$ & $39.1 \pm 7.7$ & $=0.102$ \\
\hline \multicolumn{4}{|l|}{ Functional capillary density ${ }^{a}$} \\
\hline CDcontinuous (caps/mm) & $20.8 \pm 1.7$ & $15.2 \pm 0.8$ & $=0.014$ \\
\hline CDintermittent (caps/mm) & $3.6 \pm 1.1$ & $5.8 \pm 1.1$ & NS \\
\hline CDstop (caps/mm) & $3.6 \pm 0.4$ & $8.7 \pm 1.1$ & $=0.001$ \\
\hline \multicolumn{4}{|l|}{ Capillary function ${ }^{\mathrm{b}}$} \\
\hline art response time $\left(\mathrm{SO}_{2}<20 \%\right)$ & $2.1 \pm 0.3$ & $7.5 \pm 0.9$ & $<0.001$ \\
\hline ven response time $\left(\mathrm{SO}_{2}<20 \%\right)$ & $2.6 \pm 0.7$ & $6.4 \pm 1.6$ & $=0.026$ \\
\hline \multicolumn{4}{|l|}{ RBC function } \\
\hline RBC ATP efflux $(H / N)^{c}$ & $1.48 \pm 0.10$ & $0.55 \pm 0.04$ & $<0.001$ \\
\hline
\end{tabular}

Values are mean \pm SE

${ }^{\mathrm{a}}$ Evaluated on the basis of 30-second flow behavior (intermittent flow = capillary comes to arrest for at least 1 second; stopped-flow (stop) $=$ RBCs are arrested for 30 seconds)

${ }^{\mathrm{b}}$ Capillary response time $=$ time required for capillary $\mathrm{RBC} \mathrm{SO}_{2}$ to return to values $>20 \%$

'ATP efflux where $\mathrm{H} / \mathrm{N}$ is RBC ATP efflux ratio under normoxic $(\mathrm{N}=\mathrm{RBC}$ exposure to 5 minutes $\left.21 \% \mathrm{O}_{2}\right)$ and hypoxic $(\mathrm{H}=\mathrm{RBC}$ exposure to 5 minutes $0 \% \mathrm{O}_{2}$ ) conditions

art Arteriolar end of capillary network, CD Capillary density, CLP Cecal ligation and perforation, $\mathrm{CV}$ Coefficient of variation (= SD/mean; based on 30-second $\mathrm{RBC} S \mathrm{SR}$ and $\mathrm{RBC} \mathrm{qO}_{2}$ profiles), $E R$ Extraction ratio, $q \mathrm{O}_{2}$ Capillary oxygen supply rate, $R B C$ red blood cell, $S_{2}$ Oxygen saturation, $S R$ Supply rate, ven Venular end of capillary network

animals $(p=0.102)$ compared to sham (Table 2). In addition to changes in capillary RBC hemodynamics and oxygen supply rates, functional capillary density was dramatically altered as continuous flow decreased and capillary stopped-flow increased 2.4-fold ( $p=0.001$; Table 2). See Additional file 1: Figure S2 for a labeled image of the septic microcirculation and Additional file 2 for the corresponding video clip.

\section{Capillary 30 -second $\mathrm{SR}-\mathrm{SO}_{2}-\mathrm{qO}_{2}$ profiles}

Variations in the patterns of capillary RBC SR, hemoglobin $\mathrm{SO}_{2}$ and $\mathrm{qO}_{2}$ are shown in a series of 30-second $\mathrm{SR}-\mathrm{SO}_{2}-$ $\mathrm{qO}_{2}$ profiles (Fig. 2a-d). Each capillary $\mathrm{SR}-\mathrm{SO}_{2}-\mathrm{qO}_{2}$ profile was categorized as having (slow, average, fast) SR and (low, average, high) $\mathrm{qO}_{2}$. For example, Fig. 2a depicts a capillary with continuous fast SR (18.3 RBC/s) and high $\mathrm{qO}_{2}\left(49.5 \mathrm{pLO}_{2} / \mathrm{s}\right)$, while Fig $2 \mathrm{~b}$ and $\mathrm{c}$ show average profiles, yet have distinct differences in $\mathrm{SR}$ and $\mathrm{qO}_{2}$; where the flow behavior in Fig. 2c is continuous, while it is intermittent in Fig. 2b. Figure 2d depicts a capillary with slow SR (1.6 RBC/s) and low $\mathrm{qO}_{2}\left(1.8 \mathrm{pLO}_{2} / \mathrm{s}\right)$. Distributions of capillary oxygen supply rates in sham and CLP groups are shown in Fig. 2e, f. Chi-squared analysis $\left(\chi^{2}=83.7,5 \mathrm{df}, p<\right.$ 0.05 ) indicated that differences in $\mathrm{qO}_{2}$ existed between groups, reflecting an increase in low oxygen supply rate in capillary networks in CLP animals. Thus the septic microcirculation became more heterogeneous in terms of local $\mathrm{O}_{2}$ delivery with increased numbers of capillaries having low $\mathrm{qO}_{2}$ or no $\mathrm{O}_{2}$ delivery at all (in the case of stoppedflow capillaries) and much higher oxygen supply rates in other capillaries.

\section{Capillary response time within hypoxic capillaries}

Analysis of 30 -second $\mathrm{SR}-\mathrm{SO}_{2}-\mathrm{qO}_{2}$ profiles revealed that some capillaries experienced a delayed response to periods of low capillary $\mathrm{RBC} \mathrm{SO}_{2}(<20 \%$, referred to as capillary hypoxia). The capillary response time was defined as the time required for a capillary to return to a state where $\mathrm{RBC} \mathrm{SO}_{2}>20 \%$. For example, Fig. 3a, b shows relatively short response times within capillaries with falling capillary $\mathrm{RBC} \mathrm{SO}_{2}$ (2.0 and 2.3 seconds, respectively), whereas Fig. 3c, e show much longer response times (10.5 and 7.5 seconds, respectively), while Fig. 3d shows a capillary failing to respond with $\mathrm{RBC} \mathrm{SO}_{2}<20 \%$ over the 30 -second observation period. Overall, 2.5- and 3.6-fold increases in capillary response times to $\mathrm{RBC} \mathrm{SO} 2<20 \%$ were detected at the arteriolar and venular ends of septic capillaries $(p<0.05$; Fig. $3 f)$. The response times are summarized in Table 2.

\section{Sepsis reduces $\mathrm{RBC} \mathrm{O}_{2}$-dependent ATP efflux}

Since this study found evidence of delayed capillary response times within hypoxic capillaries, we tested the null hypothesis that sepsis would have no effect on the $\mathrm{RBC}$ response to hypoxic conditions by measuring $\mathrm{RBC}$ $\mathrm{O}_{2}$-dependent ATP efflux. We found $\mathrm{RBC} \mathrm{O}_{2}$-dependent ATP efflux was impaired in septic RBCs, compromising the erythrocyte's ability to respond to hypoxic conditions. Under normal physiology, there was a large increase in ATP released from RBCs exposed to hypoxia compared to the normoxic or baseline condition. During sepsis, however, RBCs released much less ATP when exposed to hypoxia (Fig. 4a, b), measured as plasma ATP and \% change in ATP efflux, respectively. Expressed as the hypoxia/normoxia ratio, which normalizes the measurement to baseline, we found erythrocyte $\mathrm{O}_{2}$-dependent ATP efflux decreased in CLP animals (62.6\% versus sham; $1.48 \pm 0.1$ versus sham $0.55 \pm 0.06, p<0.001)$, summarized in Table 2 as RBC function. 


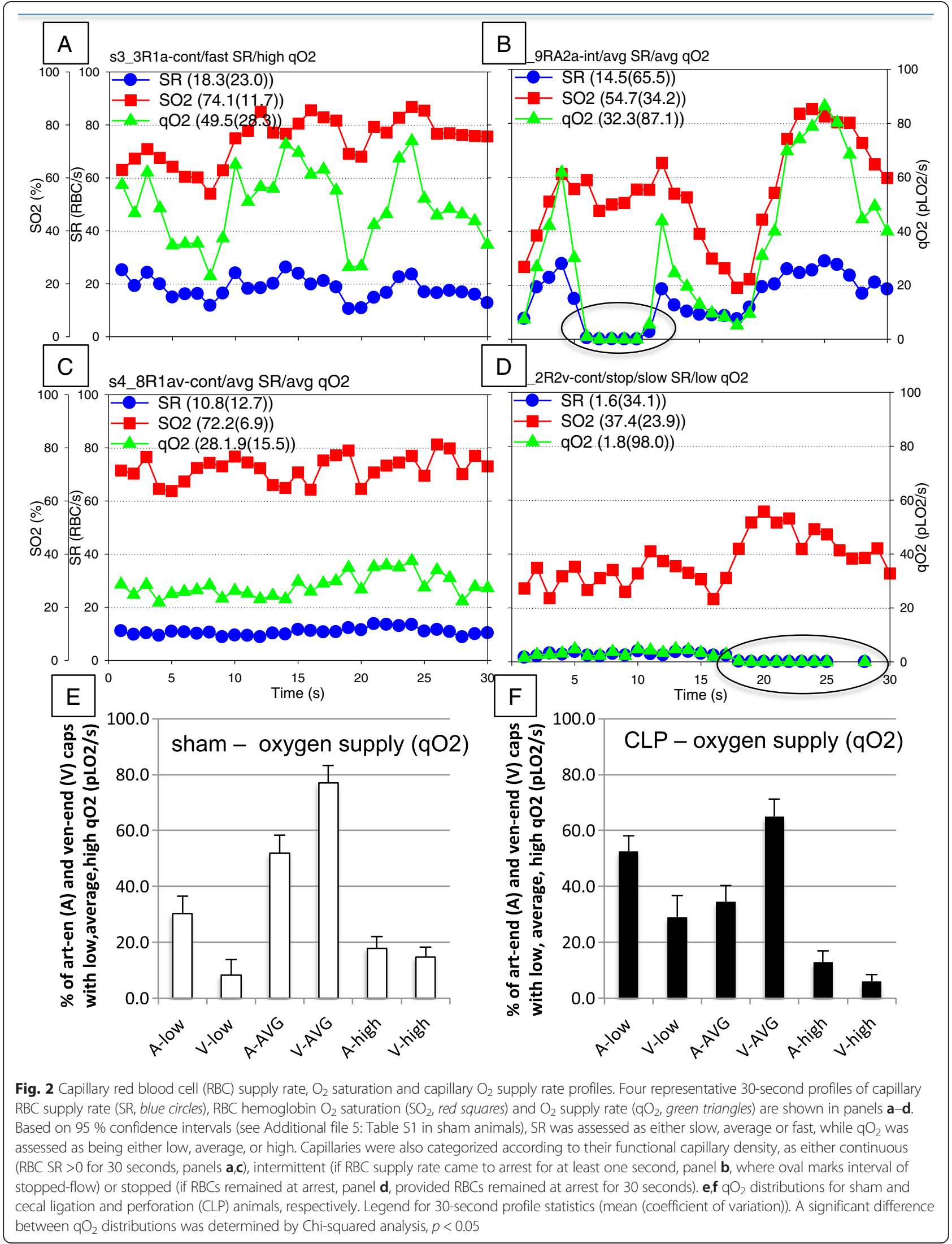




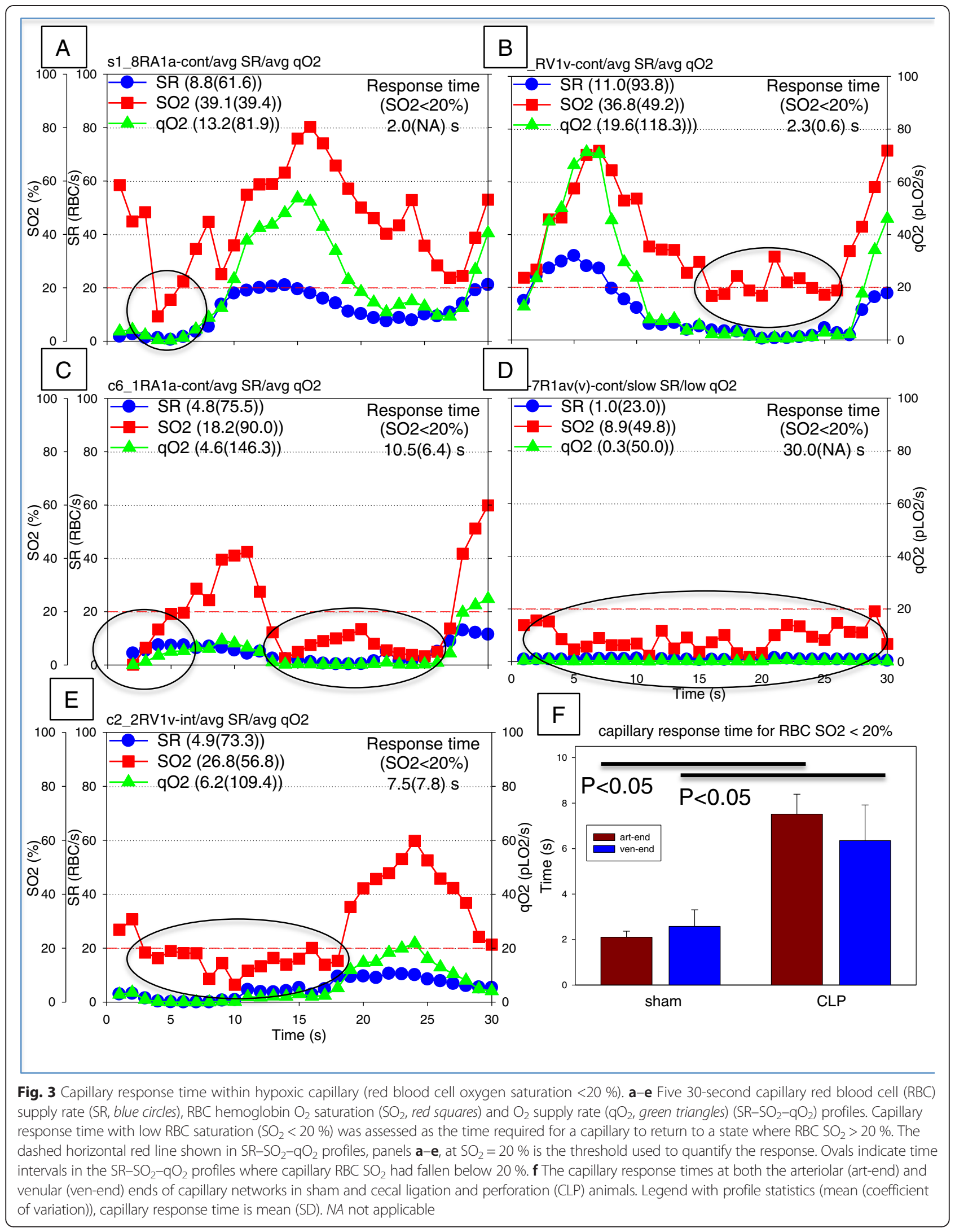




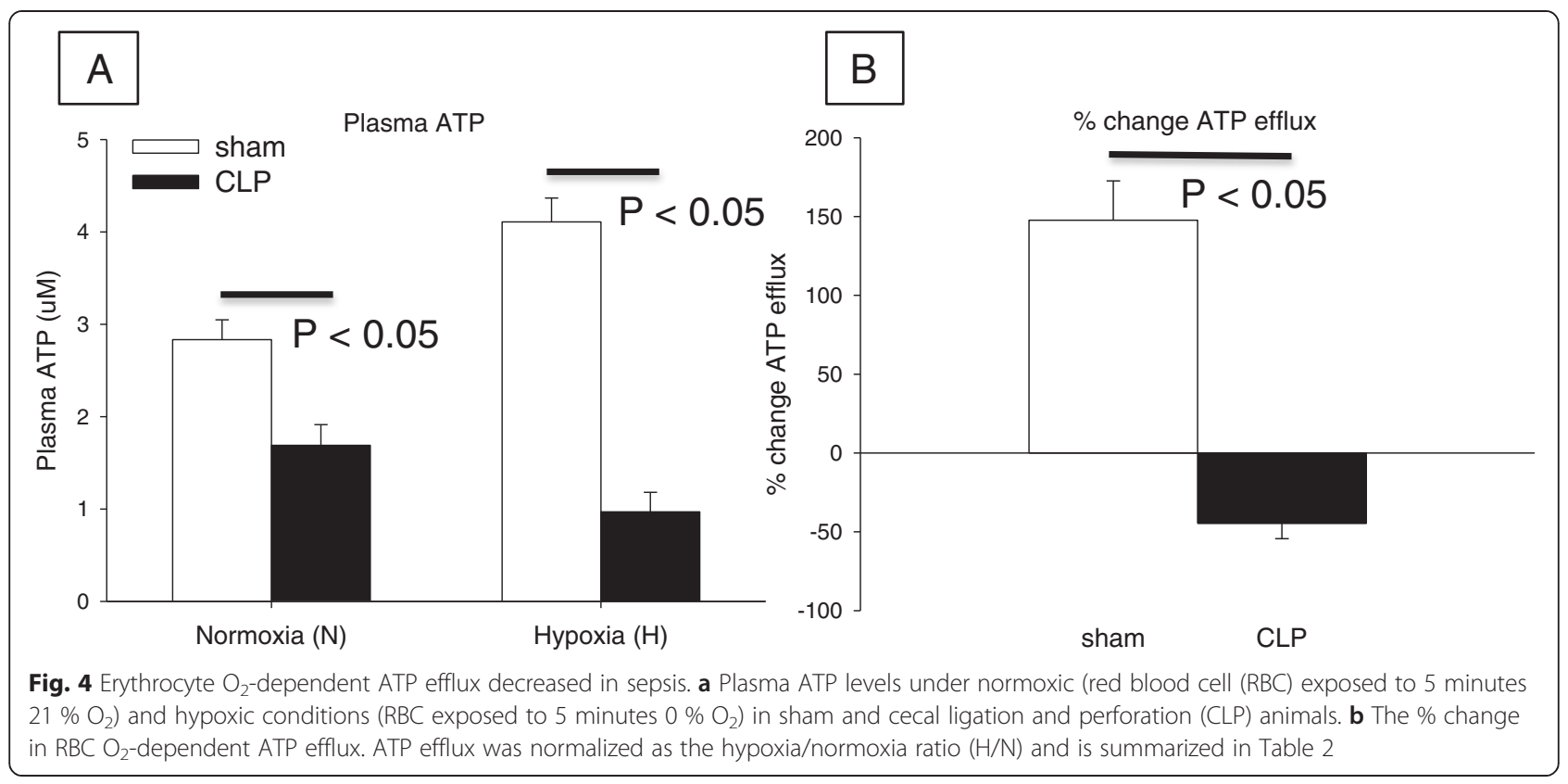

\section{Model of biophysical and metabolic factors controlling microvascular autoregulation under normal and septic conditions}

An objective of this study was to incorporate new findings on impaired microvascular autoregulation into a pathophysiological model to gain insight into the mechanisms and possible feedback loops underlying the microvascular derangements observed in skeletal muscle during sepsis. The model (Fig. 5a) simplifies this complex pathophysiology by presenting a simple framework and shows the main interactions under consideration, while limiting the model to three important negative modulators of RBC $\mathrm{O}_{2}$-dependent ATP efflux: 1) decreased RBC deformability, 2) increased lactate and 3) increased NO (which is upregulated by inducible nitric oxide synthase (iNOS) in skeletal muscle [2] in this model). At the center of the model is the erythrocyte acting as an $\mathrm{O}_{2}$ sensor $[17,23]$ responding to local partial pressure of oxygen $\left(\mathrm{PO}_{2}\right)$ gradients and shear stress-induced changes in RBC deformability. Also included in the model are a number of related $\mathrm{NO}$ and sepsis-mediated microvascular autoregulation, $\mathrm{O}_{2}$ transport and $\mathrm{O}_{2}$ consumption effects including impaired $\mathrm{RBC} \mathrm{O}_{2}$-dependent ATP release [24], inhibition of endothelial conducted vascular response [9, 25], loss of RBC deformability [22], inhibited mitochondrial function $[26,27]$ and decreased skeletal muscle $\mathrm{O}_{2}$ consumption [2], and increased vasodilation and altered vascular reactivity [28-30]. Additionally, sepsis increases plasma lactate via tissue hypoxia or phosphorylation of pyruvate dehydrogenase [31], which can feedback on the $\mathrm{RBC} \mathrm{O}_{2}$-dependent ATP efflux. Figure 5b represents the model as a flow chart. Figure 6 summarizes the metabolic, $\mathrm{RBC}$ and microvascular functional changes observed at the 6-hour end-point of this study. Figure 7 is a summary figure that extends the model concept to three levels of microvascular autoregulation including: 1) the overall capillary network (Fig. 7a) where the conducted vascular response is integrated over the capillary network, 2) the capillary (Fig. 7b) where hypoxic RBCs release ATP into the vasculature triggering the conducted vascular response via endothelial cell P2Y receptors, and 3) the RBC (Fig. 7c) where deoxyhemoglobin displaces glycolytic enzymes at the inner $\mathrm{RBC}$ membrane triggering $\mathrm{O}_{2}$ dependent ATP efflux.

\section{Discussion}

\section{Summary}

The main finding of this study was that sepsis impaired microvascular autoregulation during the initial stages of the septic injury. This was evident in two ways: 1) at the capillary level, we found a three- to fourfold delay in capillary response time within hypoxic capillaries ( $\left.\mathrm{RBC} \mathrm{SO}_{2}<20 \%\right)$ and 2) at the RBC level, we detected a significant impairment in the ability of septic $\mathrm{RBCs}$ to release ATP in response to hypoxic conditions. Both of these findings are consistent with a loss of microvascular autoregulation. In the context of sepsis, this may be important because impairment of microvascular autoregulation may lie at the center of microvascular dysfunction and be an important factor in multiple organ failure by fundamentally altering local tissue $\mathrm{O}_{2}$ transport properties, as well as delivery of nutrients, antioxidants and elimination of waste products.

The data reported here suggest there is an uncoupling of local $\mathrm{O}_{2}$ delivery from local $\mathrm{O}_{2}$ demand leaving some 


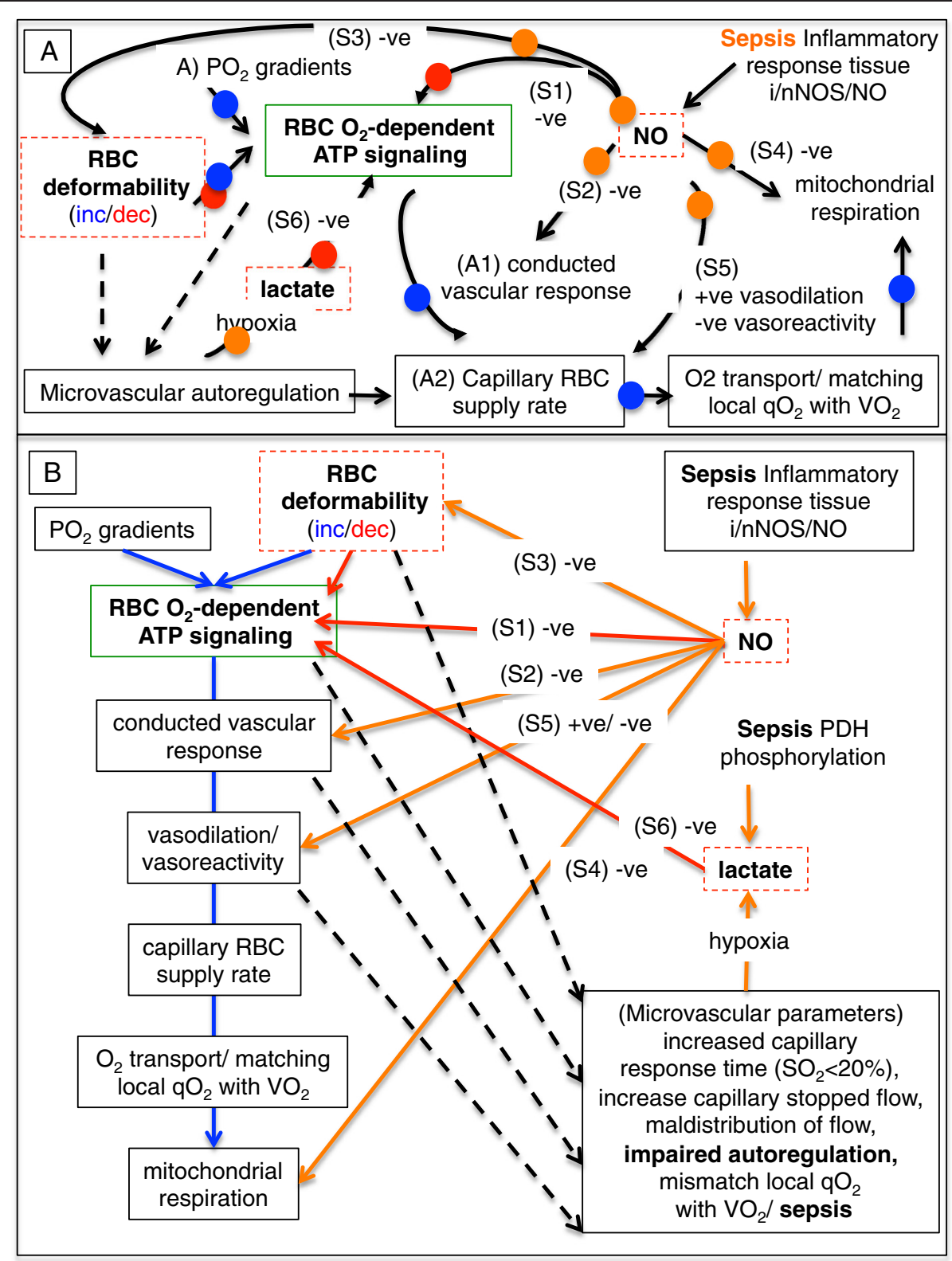

Fig. 5 Model of microvascular autoregulation. a Pathways involved in microvascular autoregulation. At the model center (green square) is red blood cell (RBC) $\mathrm{O}_{2}$-dependent ATP efflux, where RBCs act as signal transducers responding to local $\mathrm{O}_{2}$ gradients, shear stress and metabolic conditions. Blue dots (A-A2) indicate normal microvascular function whereby partial pressure of oxygen $\left(\mathrm{PO}_{2}\right)$ gradients or RBC deformation [36-38] induce RBCs to release ATP, triggering a conducted vascular response leading to increased capillary RBC supply rate [10, 11, 16], matching local $\mathrm{O}_{2}$ delivery with demand. Red dots indicate negative feedback on $\mathrm{RBC}_{2}$-dependent ATP efflux by nitric oxide (NO) [24], lactate [43] and decreased RBC deformability [42] (dashed red boxes). Multiple effects of $\mathrm{NO}$ on microvascular autoregulation, $\mathrm{O}_{2}$ transport and $\mathrm{O}_{2}$ consumption (orange dots (S1-S6)) include: S1, inhibiting RBC $\mathrm{O}_{2}$-dependent ATP efflux [24]; S2, reducing conducted vascular response [9, 25]; S3, decreasing RBC deformability [22]; S4, inhibiting mitochondrial function [26] and $\mathrm{O}_{2}$ consumption [2]; S5, inducing vasodilation, but altering vasoreactivity by inducing arteriolar hyporesponsiveness [28-30]. Sepsis increases lactate (S6) via tissue hypoxia or pyruvate dehydrogenase (PDH) phosphorylation [31], which decreases $\mathrm{RBC} \mathrm{O}_{2}$-dependent ATP efflux. Sepsis impaired microvascular autoregulation is manifested by increased capillary response time within hypoxic capillaries, attenuated $\mathrm{RBC} \mathrm{O}_{2}$-dependent ATP efflux, increased capillary stopped-flow $[2,4,5]$ and low capillary venular end $\mathrm{O}_{2}$ supply rates. $\mathbf{b}$ A flow chart of the model, where blue arrows trace normal microvascular autoregulation, red arrows show negative feedback on $\mathrm{RBC} \mathrm{O}_{2}$-dependent ATP efflux and orange arrows indicate NO-mediated effects. Dashed lines show relationships to microvascular function and autoregulation during sepsis. i/nNOS Inducible/neuronal nitric oxide synthase, $q \mathrm{O}_{2}$ Capillary $\mathrm{O}_{2}$ supply, $\mathrm{VO}_{2} \mathrm{O}_{2}$ consumption 


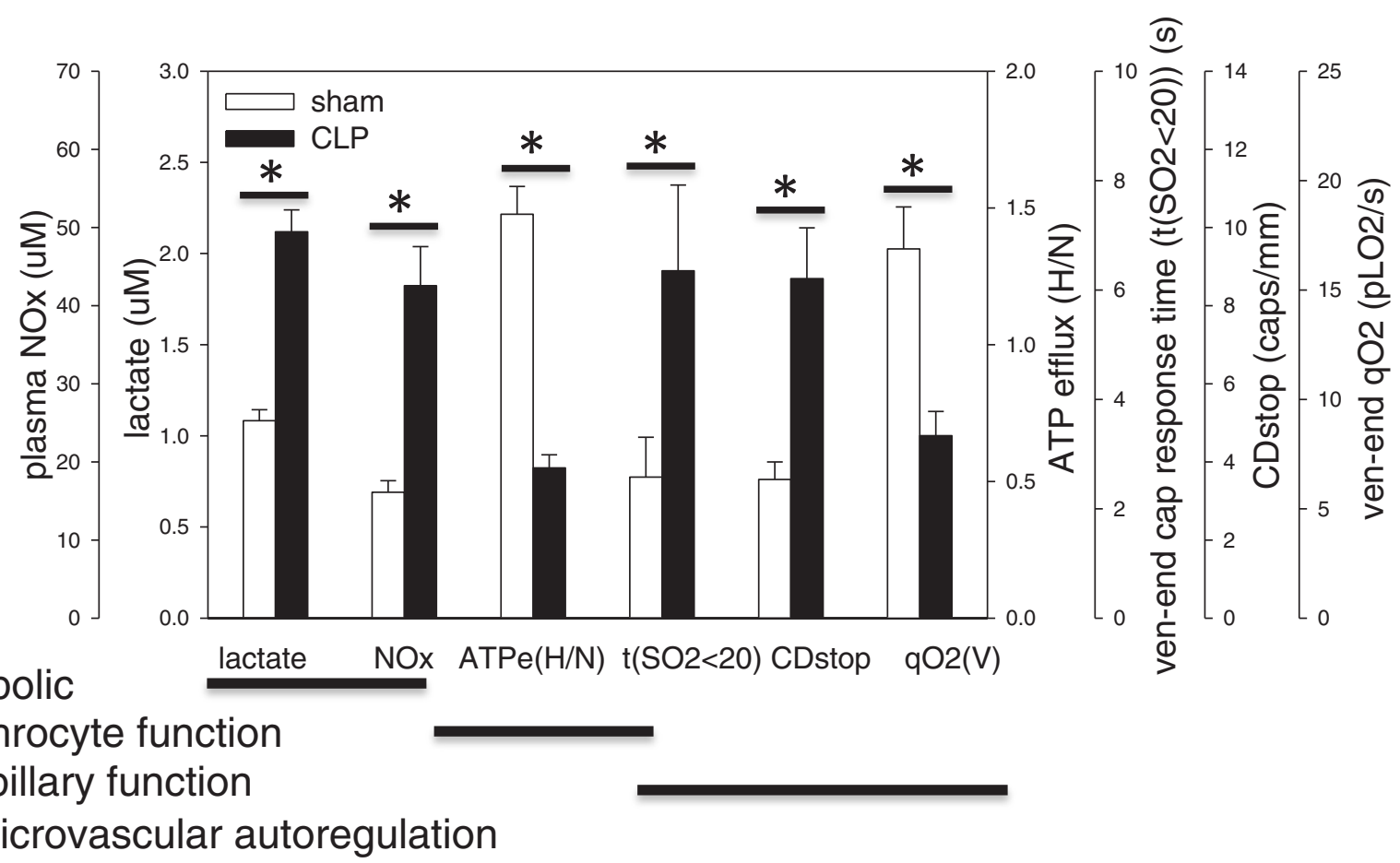

Fig. 6 Metabolic, erythrocyte and microvascular changes at the 6-hour end-point. The figure summarizes the metabolic, RBC and microvascular functional changes observed at the 6-hour end-point in this study. ATPe(H/N) RBC $\mathrm{O}_{2}$-dependent ATP efflux ratio (hypoxia/normoxia; see methods for description), CDstop Capillary density of stopped-flow capillaries, CLP Cecal ligation and perforation, NOx Nitrite + nitrate, t(SO $<20)$ Capillary response within hypoxic capillaries, where $\mathrm{t}$ is the time required for a capillary to return to a state where $\mathrm{RBC}$ oxygen saturation $\left(\mathrm{SO}_{2}\right)>20 \%$, $q \mathrm{O}_{2}(\mathrm{~V})$ Venular end $\mathrm{RBC} \mathrm{O}_{2}$ supply rate. ${ }^{*} p<0.05$

tissue regions vulnerable to hypoxia and unable to rapidly respond to $\mathrm{O}_{2}$ demand; this is consistent with Lam et al. [4], who found septic skeletal muscle had a weaker microvascular response to electrical stimulation and increased $\mathrm{O}_{2}$ demand than control. This impairment of microvascular autoregulation and capillary $\mathrm{O}_{2}$ delivery may, however, be partially offset by increased NO production [2] and local vasodilation, as skeletal muscle capillary RBC supply rate was found to correlate with increasing plasma NOx levels in this study. Previously, we detected an upregulation of iNOS within skeletal muscle, increased NO within the $\mathrm{RBC}$, and increased $\mathrm{NOx}$ within plasma and septic skeletal muscle, 3-6 hours after septic injury $[2,22]$. As NO levels increase within septic tissue, we suspect one target is smooth muscle cells surrounding the arterial resistance vessels. The resulting vasodilation would increase blood flow in these vessels causing downstream increases in capillary RBC supply rate in capillaries that remained patent. Taken together with the finding that iNOS can inhibit cNOS (where constitutive NOS is associated with microvascular autoregulation) [32], we hypothesize that a trade off occurs between local autoregulatory control of $\mathrm{O}_{2}$ delivery at the microvascular level and a more general increase in flow as vascular resistance falls in sepsis. In skeletal muscle there is also evidence of increased capillary fast flow as sepsis progresses out to 24 hours [3], suggesting fast flow may be a later response to an earlier loss of functional capillary density and microvascular autoregulation, although we found evidence of some fast flow during the onset of sepsis. While no tissue oxygenation data were collected in our model, tissue oxygenation measurements made in the septic heart [33] and simulations of tissue $\mathrm{PO}_{2}$ in septic skeletal muscle [34] have suggested the septic tissue is hypoxic, but not anoxic.

\section{Capillary $\mathrm{O}_{2}$ transport-30-second RBC SR-SO $-\mathrm{qO}_{2}$ profiles}

The imaging technique used in this study acquired highresolution information on capillary $\mathrm{RBC}$ hemodynamics ( $\mathrm{RBC}$ velocity and lineal density) and $\mathrm{RBC}$ hemoglobin $\mathrm{O}_{2}$ saturation $\left(\mathrm{SO}_{2}\right)$. From this dynamic information we calculated $\mathrm{RBC}$ supply rate (SR) and $\mathrm{O}_{2}$ supply rate $\left(\mathrm{qO}_{2}\right)$ in a capillary segment. The technology allowed a direct evaluation of capillary $\mathrm{O}_{2}$ transport parameters at locations in the microcirculation where the majority of $\mathrm{O}_{2}$ is off-loaded to tissue and $\mathrm{RBC}$ hemoglobin $\mathrm{O}_{2}$ saturations are at their lowest values. Deviations in the linear relationship between $\mathrm{RBC}$ SR and $\mathrm{qO}_{2}$ in sepsis animals (Additional file 6) suggested increased heterogeneity in 

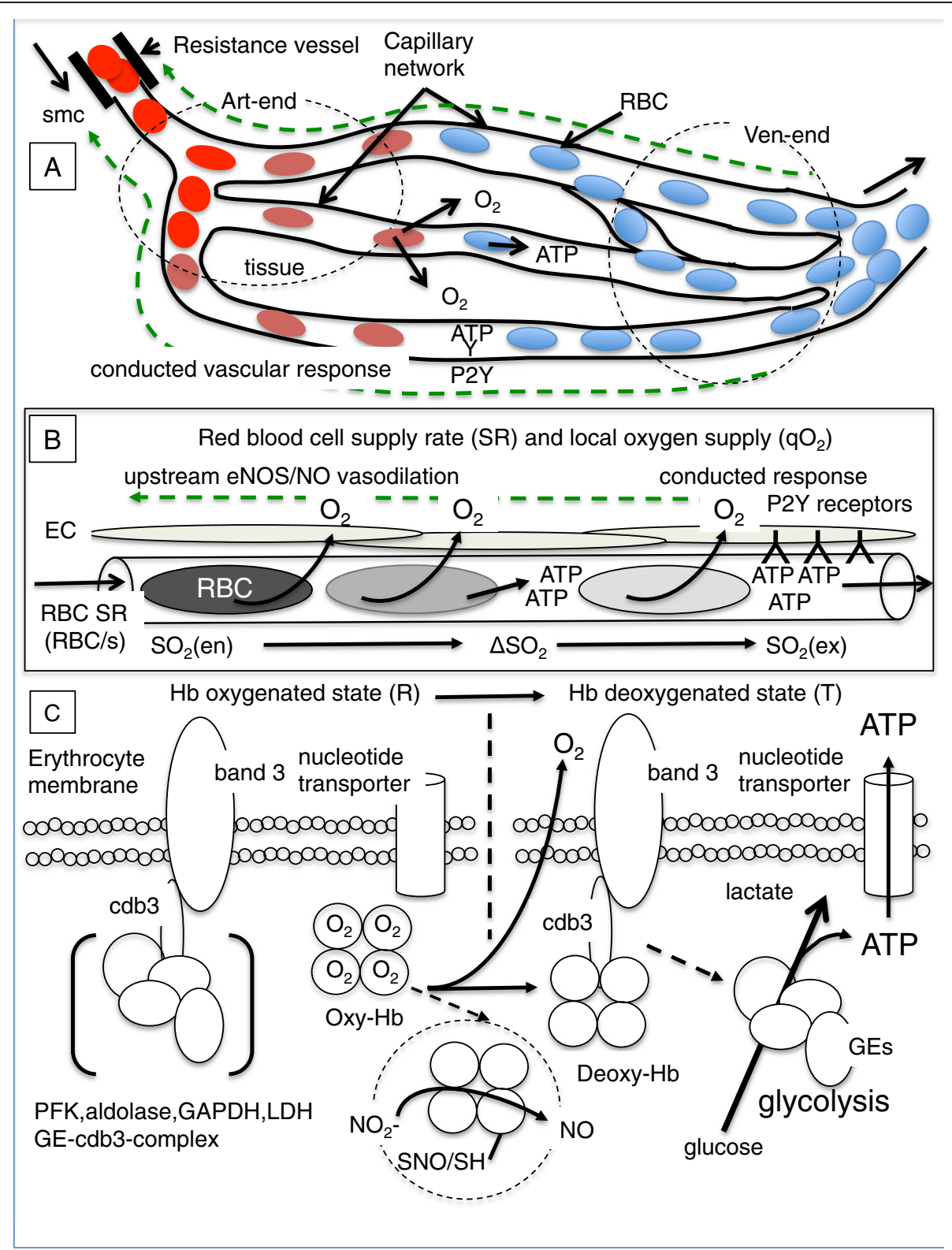

Fig. 7 Model of three-levels of microvascular autoregulation. a-c Schematics of three levels of microvascular autoregulation: 1) the overall skeletal muscle capillary network, 2) the capillary and 3) the erythrocyte, respectively. a Microvascular autoregulation at the capillary network level is viewed as the integrated conducted vascular response over the entire network feeding back to the resistance vessels [45], where nitric oxide (NO) relaxes smooth muscle vasodilating feeding arterioles, causing downstream increases in capillary red blood cell (RBC) supply rate (SR) $[10,11]$. The dashed green line represents the conducted vascular response. $\mathbf{b}$ At the capillary level is the interaction between vascular ATP (released by hypoxic RBCs) and purinergic type 2 (P2Y) receptors on endothelial cells, which trigger the conducted vascular response. c At the level of the hypoxic erythrocyte is the interaction (metabolic switch) between deoxyhemoglobin and cdb3 at the inner RBC membrane, where deoxyhemoglobin displaces glycolytic enzymes, triggering glycolysis and ATP release [13-15, 57, 58]. (Note, RBC $\mathrm{O}_{2}$-dependent ATP release is inhibited by glycolytic inhibitors, $C O$ [13] and NO [24]). The dashed circle in c shows two additional RBC mechanisms. While $\mathrm{NO}_{2}^{-}$has been reported to function in hypoxic vasodilation whereby deoxyhemoglobin converts $\mathrm{NO}_{2}^{-}$to $\mathrm{NO}[46,56]$, its role in sepsis is unclear. Similarly, it is unclear how hemoglobin-derived S-nitrosothiol [59] would function as a vasodilator in the capillary network, as capillaries are not surrounded by smooth muscle. Art-end Arteriolar end of capillaries, cdb3 Cytoplasmic domain of band 3, eNOS endothelial nitric oxide synthase, GE Glycolytic enzymes, $\mathrm{Hb}$ Hemoglobin, $\mathrm{LDH}$ Lactate dehydrogenase, $\mathrm{NO}_{2}^{-}$Nitrite, PFK Phosphofructokinase, $\mathrm{qO}_{2}$ Capillary oxygen supply rate, $R$ Relaxed $\mathrm{Hb}$ state, $\mathrm{Smc}$ Smooth muscle cell, $\mathrm{SO}_{2}$ Oxygen saturation, $T$ Tense Hb state, Ven-end Venular end of capillaries 
the underlying factors affecting the $\mathrm{SR}-\mathrm{qO}_{2}$ relationship, including heterogeneous tissue $\mathrm{O}_{2}$ consumption, maldistribution of capillary flow and impaired microvascular autoregulation.

The observed altered functional capillary density, increased capillary stopped-flow and capillaries with low $\mathrm{O}_{2}$ supply rates in the presence of very fast capillaries with high $\mathrm{O}_{2}$ supply rates were indications of increased microvascular heterogeneity, a maldistribution of capillary blood flow and a loss of microvascular autoregulation. Our findings of increased variability in the $\mathrm{O}_{2}$ supply rates and delayed capillary responses within hypoxic capillaries suggested the mechanism by which the $\mathrm{RBC}$ responds to hypoxic tissue and signals the vasculature to increase flow had been compromised during the onset of sepsis. Theoretically, arrested RBCs in stoppedflow capillaries would have the greatest potential to release ATP in response to hypoxic conditions increasing flow into the affected area. Evidence of increased capillary stopped-flow in sepsis is another indication that autoregulatory mechansims were severely impaired.

\section{Microvascular autoregulation}

While we found evidence of a delayed capillary response within hypoxic capillaries, our finding of decreased RBC $\mathrm{O}_{2}$-dependent ATP efflux was initially somewhat surprising given the low $\mathrm{RBC} \mathrm{SO}_{2}$ observed in some capillaries, as increased $\mathrm{O}_{2}$ off-loading should have induced a conformational change in hemoglobin that triggers increased ATP efflux and endothelial signaling. However, we found the opposite as ATP efflux decreased in hypoxic septic RBCs. Consistent with this inhibition of RBC ATP efflux and decreased plasma ATP levels in septic rats is the finding that plasma ATP levels are decreased in critically ill patients [35].

The association of impaired $\mathrm{RBC} \mathrm{O}_{2}$-dependent ATP efflux with increased plasma NOx and lactate suggested that multiple mechanisms are involved in modulating microvascular autoregulation. In addition to metabolic factors, since erythrocyte deformation induces ATP release [36-39], the possible inhibitory effect of decreased RBC deformability during sepsis $[22,40,41]$ on impaired RBC ATP efflux [42] must also be considered. Since we have previously shown that RBC deformability rapidly decreased during the onset of septic injury (by 3-6 hours in this animal model [22]) and decreased RBC deformability inhibits $\mathrm{RBC} \mathrm{O}_{2}$-dependent ATP release [42], it is possible that changes in the biophysical properties of the RBC membrane may be a mechanism whereby $\mathrm{RBC} \mathrm{O}_{2}$-dependent ATP efflux was impaired during sepsis. Whether age renders RBCs more susceptible to decreased deformability [41], or a particular subset of RBCs associated with decreased deformability [22] leads to impaired $\mathrm{RBC} \mathrm{O}_{2}$-dependent ATP efflux is unknown.
In addition to biophysical changes in RBC deformability, biochemical inhibition of RBC glycolysis may be another factor in impaired $\mathrm{RBC} \mathrm{O}_{2}$-dependent ATP efflux. This is consistent with in vitro experiments reporting that both $\mathrm{NO}$ [24] and lactate [43] inhibit $\mathrm{RBC}_{2}$-dependent ATP efflux and the general principle that inhibiting $\mathrm{RBC}$ glycolysis impairs $\mathrm{RBC} \mathrm{O}_{2}$-dependent ATP efflux [13]. As well, peroxynitrite, a derivative of $\mathrm{NO}$ and product of the reaction with superoxide anion, has been reported to both stimulate RBC glycolysis at low concentrations via band3 phosphorylation and irreversibly inhibit RBC glycolysis at higher concentrations [44].

In addition to impaired $\mathrm{RBC} \mathrm{O}_{2}$-dependent ATP signaling, we recognize that impaired electrical coupling of endothelial cell signaling [9] and impaired integrated capillary signaling due to increased capillary stopped-flow [45] at the overall network level of autoregulation may also have been factors in the observed impaired microvascular autoregulation. While it was beyond the scope of this study, we also note that deoxyhemoglobin has been reported to convert nitrite anion to nitric oxide [46], raising the possibility that RBCs within hypoxic capillaries were able to exert a dual level of control over microvascular autoregulation by 1) inhibiting ATP release [24] (the hypoxic ATP signal from the RBC) and/ or 2) inhibiting endothelial cell communication via $\mathrm{NO}$ release [9] (the relay mechanism by which hypoxic regions communicate with resistance vessels to increase downstream flow).

However, since capillaries are not surrounded by smooth muscle any NO or NO derivatives released from hypoxic RBCs would have no direct vasodilatory effect at the venular ends of skeletal muscle capillary networks, where the lowest $\mathrm{RBC} \mathrm{O}_{2}$ saturations are detected, and thus neither of the reported hemoglobin-mediated vascular modulators, nitrite [46] nor the more controversial S-nitrosohemoglobin [47-49], were capable of having direct vasodilatory effects in the capillary networks where the lowest $\mathrm{RBC}$ hemoglobin $\mathrm{O}_{2}$ saturations have been detected. The resistance vessels upstream of the capillary network are surrounded by smooth muscle and are NO targets; however, arterial $\mathrm{O}_{2}$ saturations are unchanged in this sepsis model making release of NO from RBCs (or ATP release) along the arterial tree less likely. However, it is conceivable that feeding arterioles neighboring hypoxic tissue regions could be NO targets. Thus the source and targets of $\mathrm{NO}$ within the microvascular system during sepsis become of paramount importance in terms of microvascular autoregulation.

While NO is known to inhibit microvascular autoregulation at multiple points in the system (Fig. 5), and may be acting in a negative feedback loop controlling RBC function, we found that increases in arterial NOx correlated with increased capillary RBC supply rate in septic 
skeletal muscle, suggesting a shift from local control of capillary perfusion via endothelial NOS/NO to a more uncontrolled, but faster delivery of blood flow, as skeletal muscle iNOS/NO rapidly increased in this model [2]. Consistent with this observation, iNOS/NO overproduction is considered a factor for increased coronary circulation during sepsis [50]. Increased NO is also responsible for systemic vasodilation and arteriolar hyporesponsiveness [29, 30]. Thus the pleotropic effects of $\mathrm{NO}$ on the cardiovascular system in general and the microcirculation in particular place $\mathrm{NO}$ in a central role in modulating microvascular autoregulation. Of further significance to overall organ function during sepsis is that $\mathrm{NO}$ inhibits mitochondrial respiration $[26,27]$ dampening $\mathrm{O}_{2}$ consumption during the onset of sepsis in our experimental model [2] and seemingly inhibiting $\mathrm{O}_{2}$ consumption when microvascular $\mathrm{O}_{2}$ delivery is compromised. Decreasing oxygen consumption in hypoxic regions is possibly an additional protective mechanism [51] that prevents tissue anoxia and certain cell death by decreasing $\mathrm{O}_{2}$ consumption and thereby increasing $\mathrm{O}_{2}$ diffusion distances in septic tissue with decreased capillary density. As well, similar responses in terms of NO upregulation and microvascular derangements are evident in the septic diaphragm and heart. If impairment of microvascular autoregulation does indeed exist in other septic organs, it may help explain altered gene expression in the septic heart [33], as it responds to local hypoxia. Additional file 7 discusses broader implications of impaired microvascular autoregulation.

\section{Study limitations and considerations}

This study was specifically designed to consider skeletal muscle microvascular function at the capillary level and test the null hypothesis that sepsis has no effect on RBC $\mathrm{O}_{2}$-dependent ATP efflux. Changes in capillary $\mathrm{O}_{2}$ supply rate are due in part to upstream changes in arteriolar tone distant from sites where $\mathrm{RBC} \mathrm{O}_{2}$ saturation is lowest (the venular ends of capillary networks) indicating that conducted microvascular responses [16, 25, 45] are integral to microvascular autoregulation. The other important distinctions to be made are: 1) the septic injury in this study does not involve systemic hypoxia, as arterial $\mathrm{O}_{2}$ saturations were normal; rather, altered functional capillary density and micro-regions within capillary networks with stopped-flow or decreased capillary $\mathrm{O}_{2}$ supply cause local hypoxia and thus a different mechanism is likely involved than that of hypoxic vasodilation [23, 46, 52]; 2) the skeletal muscle $\mathrm{NO}$ environment in this model is known to be due to an upregulation of iNOS [2]; 3) microvascular derangements exist in the face of hypotensive [2], "relatively preserved" [7] and even normotensive blood pressure $[3,4]$ with fluid resuscitation, normal arterial $\mathrm{O}_{2}$ concentration and cardiac output $[3,4]$. Thus microvascular dysfunction is apparently independent of mean arterial pressure and may be masked by seemingly normal cardiovascular parameters.

Increased arterial and tissue NOx previously reported in this sepsis model [2] are suspected to result from $\mathrm{NO}$ oxidation reactions and the scavenging effects of oxy- and deoxyhemoglobin on NO [53, 54]; however, previous EPR (Electron paramagnetic resonance) spectroscopy studies in our model have shown an accumulation of hemoglobinNO [22] in the septic RBC suggesting that NO could be accumulating within the $\mathrm{RBC}$ or regenerated by the $\mathrm{RBC}$ itself [46], although the extent and effect of such a reaction in the context of tissue iNOS/NO upregulation and overproduction [2] is unclear. While NO generated within the $\mathrm{RBC}$, possibly by an RBC NOS [55], could inhibit RBC glycolysis [44] effectively reducing the $\mathrm{RBC} \mathrm{O}_{2}$-dependent ATP efflux [24] in a negative feedback manner, the mechanism in sepsis is not understood. Any possible effects of $\mathrm{NO}_{2}^{-}$potentiating ATP efflux [56] are unknown.

\section{Future work}

This study raises an important question-specifically, can the septic microcirculation be rescued by preventing the delayed capillary response within hypoxic capillaries with low $\mathrm{RBC} \mathrm{SO}_{2}$ or rescuing $\mathrm{RBC} \mathrm{O}_{2}$-dependent ATP signaling? Or is it more important to consider the entire microvascular autoregulatory system as a functional unit [1], including $\mathrm{RBC} \mathrm{O}_{2}$-dependent ATP signaling, endothelial cell communication, vascular reactivity and $\mathrm{NO}$ overproduction that together need to be regulated and restored in order to rescue the septic microcirculation and improve capillary response times.

\section{Conclusion}

While septic erythrocytes remained capable of off-loading increased amounts of $\mathrm{O}_{2}$ within septic capillaries, both the capillary response within hypoxic capillaries and the septic $\mathrm{RBC} \mathrm{O}_{2}$-dependent ATP response to hypoxia were impaired. This impairment of the $\mathrm{RBC}$ to fully respond to its $\mathrm{O}_{2}$ environment was likely a factor in the delayed capillary response with low $\mathrm{RBC} \mathrm{O}_{2}$ saturations, although other factors were likely involved including attenuated endothelial cell-conducted vascular response and altered vasoreactivity. Accordingly, treatments aimed at restoring the autoregulation of the septic microcirculation may be of benefit to the septic patient, provided the complete microvascular autoregulatory system can be rescued simultaneously. However, further research will be required to form a more complete understanding of how microvascular autoregulation is operating in both health and disease states.

\section{Key messages}

- Sepsis attenuates the capillary response within hypoxic capillaries. 
- Septic erythrocytes are impaired from releasing ATP in response to hypoxic conditions.

- Sepsis-induced impairment of microvascular autoregulation is partially off-set by increased capillary $\mathrm{RBC}$ supply rate, which correlates with increased plasma NOx.

- Sepsis induces profound disturbances in microvascular function and control.

- Microvascular autoregulation is impaired at three levels: 1) the RBC level, 2) the capillary level and 3) the overall capillary network level.

\section{Additional files}

\section{Additional file 1: Data supplement including information on methods. (PDF $927 \mathrm{~kb}$ )}

Additional file 2: Video clip of skeletal muscle capillary red blood cell (RBC) hemodynamics. (MOV $4983 \mathrm{~kb}$ )

Additional file 3: Video clip of skeletal muscle capillary red blood cell hemoglobin $\mathbf{O}_{2}$ saturation (RBC SO $\mathbf{2}_{2}$ ). (MOV $4923 \mathrm{~kb}$ )

Additional file 4: $\mathrm{RBC}$ supply rate $(\mathrm{SR})$ and $\mathrm{O}_{2}$ supply rate $\left(\mathrm{qO}_{2}\right)$ heterogeneity. (PDF $285 \mathrm{~kb}$ )

Additional file 5: Control capillary RBC supply rate and $\mathrm{O}_{2}$ supply rate $95 \%$ confidence intervals. (PDF $56 \mathrm{~kb}$ )

Additional file 6: Relationship between capillary RBC supply rate and $\mathrm{O}_{2}$ supply rate. (PDF $234 \mathrm{~kb}$ )

Additional file 7: Broader implications of impaired microvascular autoregulation in skeletal muscle. (PDF $50 \mathrm{~kb}$ )

\section{Abbreviations}

CLP: Cecal ligation and perforation; iNOS: Inducible nitric oxide synthase; $\mathrm{NO}$ : Nitric oxide; $\mathrm{NOx}$ : $\mathrm{NO}_{2}^{-}+\mathrm{NO}_{3}^{-} ; \mathrm{O}_{2}$ : Oxygen; OD: Optical density; P2Y: Purinergic type 2; $\mathrm{PO}_{2}$ : Partial pressure of oxygen; $\mathrm{qO}_{2}$ : Capillary oxygen supply rate; $\mathrm{RBC}$ : Red blood cell; $\mathrm{SO}_{2}$ : Oxygen saturation; $\mathrm{SR}$ : RBC supply rate.

\section{Competing interests}

The authors declare that they have no competing interests.

\section{Authors' contributions}

RMB designed research, optimized nitric oxide analysis, performed all experiments and statistical analysis, developed models and wrote the manuscript. JEJ designed gas exchange experimental apparatus, developed the ATP assay, discussed research and edited the manuscript. MDS participated in the design of the study, discussed research and edited the manuscript. CGE developed the microvascular imaging and analysis system, discussed research and edited the manuscript. All authors have read and approved the final version of the manuscript.

\section{Acknowledgements}

The authors gratefully thank Livio Rigutto for constructing the light tight box, Stephanie Milkovich for calibrating the imaging system, Lawrence Lee for help with video post production and Dr. Nathan Shapiro for helpful discussions. Funded, in part, by research grant MOP-499416 from Canadian Institutes of Health, London, ON, Canada, University of Western Ontario (CGE). RMB was supported in part by the Spoerel Research Fellowship (London, ON, Canada).

\section{Author details}

${ }^{1}$ Department of Medical Biophysics, University of Western Ontario, London, ON, Canada. ${ }^{2}$ Department of Biochemistry, Keio University School of Medicine, Tokyo, Japan. ${ }^{3}$ Ryleeon, 18519-77 Ave NW, Edmonton, AB T5T6A8, Canada. ${ }^{4}$ Department of Anesthesia and Critical Care Western, University of Western Ontario, London, ON, Canada.
Received: 26 June 2015 Accepted: 16 October 2015

Published online: 05 November 2015

\section{References}

1. Bateman RM, Sharpe MD, Ellis CG. Bench-to-bedside review: microvascular dysfunction in sepsis - hemodynamics, oxygen transport, and nitric oxide. Crit Care. 2003;7:359-73.

2. Bateman RM, Sharpe MD, Goldman D, Lidington D, Ellis CG. Inhibiting nitric oxide overproduction during hypotensive sepsis increases local oxygen consumption in rat skeletal muscle. Crit Care Med. 2008;36:225-31.

3. Ellis CG, Bateman RM, Sharpe MD, Sibbald WJ, Gill R. Effect of a maldistribution of microvascular blood flow on capillary $\mathrm{O}(2)$ extraction in sepsis. Am J Physiol Heart Circ Physiol. 2002;282:H156-64.

4. Lam C, Tyml K, Martin C, Sibbald W. Microvascular perfusion is impaired in a rat model of normotensive sepsis. J Clin Invest. 1994;94:2077-83.

5. De Backer D, Creteur J, Preiser JC, Dubois MJ, Vincent JL. Microvascular blood flow is altered in patients with sepsis. Am J Respir Crit Care Med. 2002;166:98-104.

6. Hernandez G, Boerma EC, Dubin A, Bruhn A, Koopmans M, Edul VK, et al. Severe abnormalities in microvascular perfused vessel density are associated to organ dysfunctions and mortality and can be predicted by hyperlactatemia and norepinephrine requirements in septic shock patients. J Crit Care. 2013;28:e9-14.

7. De Backer D, Donadello K, Sakr Y, Ospina-Tascon G, Salgado D, Scolletta S, et al. Microcirculatory alterations in patients with severe sepsis: impact of time of assessment and relationship with outcome. Crit Care Med. 2013;41:791-9

8. Trzeciak S, Dellinger RP, Parrillo JE, Guglielmi M, Bajaj J, Abate NL, et al. Early microcirculatory perfusion derangements in patients with severe sepsis and septic shock: relationship to hemodynamics, oxygen transport, and survival. Ann Emerg Med. 2007;49:88-98. 98.e1-2.

9. McKinnon RL, Lidington D, Bolon M, Ouellette Y, Kidder GM, Tyml K. Reduced arteriolar conducted vasoconstriction in septic mouse cremaster muscle is mediated by nNOS-derived NO. Cardiovasc Res. 2006;69:236-44.

10. Ellsworth ML, Forrester T, Ellis CG, Dietrich HH. The erythrocyte as a regulator of vascular tone. Am J Physiol. 1995;269:H2155-61.

11. Sprague RS, Hanson MS, Achilleus D, Bowles EA, Stephenson AH, Sridharan $\mathrm{M}$, et al. Rabbit erythrocytes release ATP and dilate skeletal muscle arterioles in the presence of reduced oxygen tension. Pharmacol Rep. 2009;61:183-90.

12. Bergfeld GR, Forrester T. Release of ATP from human erythrocytes in response to a brief period of hypoxia and hypercapnia. Cardiovasc Res. 1992;26:40-7.

13. Jagger JE, Bateman RM, Ellsworth ML, Ellis CG. Role of erythrocyte in regulating local $\mathrm{O} 2$ delivery mediated by hemoglobin oxygenation. Am J Physiol Heart Circ Physiol. 2001;280:H2833-9.

14. Lewis IA, Campanella ME, Markley JL, Low PS. Role of band 3 in regulating metabolic flux of red blood cells. Proc Natl Acad Sci U S A. 2009; 106:18515-20.

15. Messana I, Orlando M, Cassiano L, Pennacchietti L, Zuppi C, Castagnola M, et al. Human erythrocyte metabolism is modulated by the O2-linked transition of hemoglobin. FEBS Lett. 1996;390:25-8.

16. Collins DM, McCullough WT, Ellsworth ML. Conducted vascular responses: communication across the capillary bed. Microvasc Res. 1998;56:43-53.

17. Ellsworth ML. The red blood cell as an oxygen sensor: what is the evidence? Acta Physiol Scand. 2000;168:551-9.

18. Bateman RM, Ellis CG, Sharpe MD, Mehta S, Freeman DJ. Effect of hemolyzed plasma on the batch measurement of nitrate by nitric oxide chemiluminescence. Clin Chem. 2001;47:1847-51.

19. Bateman RM, Ellis CG, Freeman DJ. Optimization of nitric oxide chemiluminescence operating conditions for measurement of plasma nitrite and nitrate. Clin Chem. 2002;48:570-3.

20. Japee SA, Pittman RN, Ellis CG. A new video image analysis system to study red blood cell dynamics and oxygenation in capillary networks. Microcirculation. 2005;12:489-506.

21. Ellsworth ML, Pittman RN, Ellis CG. Measurement of hemoglobin oxygen saturation in capillaries. Am J Physiol. 1987;252:H1031-40.

22. Bateman RM, Jagger JE, Sharpe MD, Ellsworth ML, Mehta S, Ellis CG. Erythrocyte deformability is a nitric oxide-mediated factor in decreased capillary density during sepsis. Am J Physiol Heart Circ Physiol. 2001;280:H2848-56. 
23. Crawford JH, Isbell TS, Huang Z, Shiva S, Chacko BK, Schechter AN, et al. Hypoxia, red blood cells, and nitrite regulate NO-dependent hypoxic vasodilation. Blood. 2006;107:566-74.

24. Olearczyk JJ, Ellsworth ML, Stephenson AH, Lonigro AJ, Sprague RS. Nitric oxide inhibits ATP release from erythrocytes. J Pharmacol Exp Ther. 2004;309:1079-84.

25. McKinnon RL, Bolon ML, Wang HX, Swarbreck S, Kidder GM, Simon AM, et al. Reduction of electrical coupling between microvascular endothelial cells by NO depends on connexin37. Am J Physiol Heart Circ Physiol. 2009;297:H93-101.

26. Davies NA, Cooper CE, Stidwill R, Singer M. Inhibition of mitochondrial respiration during early stage sepsis. Adv Exp Med Biol. 2003;530:725-36

27. Frost MT, Wang Q, Moncada S, Singer M. Hypoxia accelerates nitric oxidedependent inhibition of mitochondrial complex I in activated macrophages. Am J Physiol Regul Integr Comp Physiol. 2005;288:R394-400.

28. Tyml K, Yu J, McCormack DG. Capillary and arteriolar responses to local vasodilators are impaired in a rat model of sepsis. J Appl Physiol. 1998;84:837-44.

29. Hollenberg SM, Cunnion RE, Zimmerberg J. Nitric oxide synthase inhibition reverses arteriolar hyporesponsiveness to catecholamines in septic rats. Am J Physiol. 1993;264:H660-3.

30. Hollenberg SM, Piotrowski MJ, Parrillo JE. Nitric oxide synthase inhibition reverses arteriolar hyporesponsiveness to endothelin-1 in septic rats. Am J Physiol. 1997;272:R969-74.

31. Vary TC. Sepsis-induced alterations in pyruvate dehydrogenase complex activity in rat skeletal muscle: effects on plasma lactate. Shock. 1996;6:89-94.

32. Scott JA, Mehta S, Duggan M, Bihari A, McCormack DG. Functional inhibition of constitutive nitric oxide synthase in a rat model of sepsis.

Am J Respir Crit Care Med. 2002;165:1426-32.

33. Bateman RM, Tokunaga C, Kareco T, Dorscheid DR, Walley KR. Myocardial hypoxia-inducible HIF-1alpha, VEGF, and GLUT1 gene expression is associated with microvascular and ICAM-1 heterogeneity during endotoxemia. Am J Physiol Heart Circ Physiol. 2007;293:H448-56.

34. Goldman D, Bateman RM, Ellis CG. Effect of sepsis on skeletal muscle oxygen consumption and tissue oxygenation: interpreting capillary oxygen transport data using a mathematical model. Am J Physiol Heart Circ Physiol. 2004;287:H2535-44.

35. Chida J, Ono R, Yamane K, Hiyoshi M, Nishimura M, Onodera M, et al. Blood lactate/ATP ratio, as an alarm index and real-time biomarker in critical illness. PLoS One. 2013;8:e60561.

36. Faris A, Spence DM. Measuring the simultaneous effects of hypoxia and deformation on ATP release from erythrocytes. Analyst. 2008;133:678-82.

37. Forsyth AM, Wan J, Owrutsky PD, Abkarian M, Stone HA. Multiscale approach to link red blood cell dynamics, shear viscosity, and ATP release. Proc Natl Acad Sci U S A. 2011;108:10986-91.

38. Sprague RS, Ellsworth ML, Stephenson AH, Kleinhenz ME, Lonigro AJ. Deformation-induced ATP release from red blood cells requires CFTR activity. Am J Physiol. 1998;275:H1726-32.

39. Sprague RS, Ellsworth ML, Stephenson AH, Lonigro AJ. ATP: the red blood cell link to NO and local control of the pulmonary circulation. Am J Physiol. 1996;271:H2717-22.

40. Baskurt OK, Gelmont D, Meiselman HJ. Red blood cell deformability in sepsis. Am J Respir Crit Care Med. 1998;157:421-7.

41. Condon MR, Kim JE, Deitch EA, Machiedo GW, Spolarics Z. Appearance of an erythrocyte population with decreased deformability and hemoglobin content following sepsis. Am J Physiol Heart Circ Physiol. 2003;284:H2177-84.

42. Sridharan M, Sprague RS, Adderley SP, Bowles EA, Ellsworth ML, Stephenson $\mathrm{AH}$. Diamide decreases deformability of rabbit erythrocytes and attenuates low oxygen tension-induced ATP release. Exp Biol Med. 2010;235:1142-8.

43. Rozier MD, Zata VJ, Ellsworth ML. Lactate interferes with ATP release from red blood cells. Am J Physiol Heart Circ Physiol. 2007;292:H3038-42.

44. Mallozzi C, Di Stasi AM, Minetti M. Peroxynitrite modulates tyrosine-dependent signal transduction pathway of human erythrocyte band 3. FASEB J. 1997;11:1281-90.

45. Ellis CG, Milkovich S, Goldman D. What is the efficiency of ATP signaling from erythrocytes to regulate distribution of $\mathrm{O}(2)$ supply within the microvasculature? Microcirculation. 2012;19:440-50.

46. Cosby K, Partovi KS, Crawford JH, Patel RP, Reiter CD, Martyr S, et al. Nitrite reduction to nitric oxide by deoxyhemoglobin vasodilates the human circulation. Nat Med. 2003;9:1498-505.
47. Isbell TS, Sun CW, Wu LC, Teng X, Vitturi DA, Branch BG, et al. SNO-hemoglobin is not essential for red blood cell-dependent hypoxic vasodilation. Nat Med. 2008;14:773-7.

48. Zhang R, Hess DT, Qian Z, Hausladen A, Fonseca F, Chaube R, et al. Hemoglobin betaCys93 is essential for cardiovascular function and integrated response to hypoxia. Proc Natl Acad Sci U S A. 2015;112:6425-30.

49. Liu Y, Sun CW, Honavar J, Townes T, Patel RP. Role of the b93cys, ATP and adenosine in red cell dependent hypoxic vasorelaxation. Int J Physiol Pathophysiol Pharmacol. 2013;5:21-31.

50. Rudiger A, Singer M. Mechanisms of sepsis-induced cardiac dysfunction. Crit Care Med. 2007;35:1599-608.

51. Singer $M$, De Santis $V$, Vitale $D$, Jeffcoate $W$. Multiorgan failure is an adaptive, endocrine-mediated, metabolic response to overwhelming systemic inflammation. Lancet. 2004;364:545-8.

52. Umbrello M, Dyson A, Pinto BB, Fernandez BO, Simon V, Feelisch $M$, et al. Short-term hypoxic vasodilation in vivo is mediated by bioactive nitric oxide metabolites, rather than free nitric oxide derived from haemoglobin-mediated nitrite reduction. J Physiol. 2014;592:1061-75.

53. Isbell TS, Gladwin MT, Patel RP. Hemoglobin oxygen fractional saturation regulates nitrite-dependent vasodilation of aortic ring bioassays. Am J Physiol Heart Circ Physiol. 2007;293:H2565-72.

54. Azarov I, Huang KT, Basu S, Gladwin MT, Hogg N, Kim-Shapiro DB. Nitric oxide scavenging by red blood cells as a function of hematocrit and oxygenation. J Biol Chem. 2005;280:39024-32.

55. Ulker P, Gunduz F, Meiselman HJ, Baskurt OK. Nitric oxide generated by red blood cells following exposure to shear stress dilates isolated small mesenteric arteries under hypoxic conditions. Clin Hemorheol Microcirc. 2013:54:357-69.

56. Cao Z, Bell JB, Mohanty JG, Nagababu E, Rifkind JM. Nitrite enhances RBC hypoxic ATP synthesis and the release of ATP into the vasculature: a new mechanism for nitrite-induced vasodilation. Am J Physiol Heart Circ Physiol. 2009;297:H1494-503.

57. Campanella ME, Chu H, Low PS. Assembly and regulation of a glycolytic enzyme complex on the human erythrocyte membrane. Proc Natl Acad Sci U S A. 2005;102:2402-7.

58. Sega MF, Chu H, Christian J, Low PS. Interaction of deoxyhemoglobin with the cytoplasmic domain of murine erythrocyte band 3. Biochemistry. 2012;51:3264-72.

59. Pawloski JR, Hess DT, Stamler JS. Export by red blood cells of nitric oxide bioactivity. Nature. 2001;409:622-6.

\section{Submit your next manuscript to BioMed Central and take full advantage of:}

- Convenient online submission

- Thorough peer review

- No space constraints or color figure charges

- Immediate publication on acceptance

- Inclusion in PubMed, CAS, Scopus and Google Scholar

- Research which is freely available for redistribution 